to shipping gave a great impetus to the coal trade, the output in 1845 being three times that of 1800 . Great progress has been made during the past fifty years in the technique of coal mining, and in many collieries the only manual labour now used in the actual coal-getting is shovelling the machine-cut coal at the face on to a band- or jig-conveyor. In $1900,1.47$ per cent of the coal raised in Great Britain, and 24.9 per cent of that raised in the United States, was machine-mined; in 1932 the figures were 38 and $68 \cdot 3$ per cent respectively. Natural conditions in the United States, however, are better suited than those of many British coalfields to this mode of working. The methods of supporting the roofs and sides of underground roads are now undergoing considerable change; of the 20,000 miles of main roadways in coal mines of Great Britain, 1,800 miles are supported by steel arches, and there are in addition about 900,000 steel props used in and about the workings. The ultimate possible demand for steel supports in Great Britain is 370,000 tons a year, a quantity which would provide employment for at least 10,000 workers. Turning to the subject of accidents, Sir Richard said that, of the larger coal-producing countries, the most favourable figures are shown by France with a deathrate of 1.0 in a thousand; other figures are $1 \cdot 1$ for Great Britain and Belgium, and $4 \cdot 8$ (bituminous coal) and 3.9 (anthracite) for the United States. The future of the coal trade is dependent, in Sir Richard's view, on increased scientific research and the discovery of new uses for coal.

\section{University Degrees in Engineering}

IN the Engineer for November 2 is the first of a series of articles on "University Degrees in Engineering", and the subject is referred to in a leading article. One aspect of this question, namely, the new regulations for 'external' degrees in engineer. ing of the University of London, was discussed in NAture of August 12, 1933, p. 222. It is well known, says the Engineer, that regulations and customs governing the granting by British universities of degrees in engineering are not uniform, each university being a law unto itself. The values of degrees, therefore, differ greatly. While it is admitted that to ask the universities to reduce themselves to a dead level of uniformity as regards the standard of their products would be to aim a blow at the very root of the conception behind university instruction and education, yet it is impossible to shut one's eyes to the fact that some measure of standardisation of the conditions under which engineering degrees are granted is overdue. As an impartial observer, the Engineer considers that unless the problem is attacked thoroughly and soon, the reputation of university degrees for engineers will suffer a severe decline. How the regulations differ is shown in the first of the articles in the series, which deals with engineering degrees granted by the Universities of Glasgow, Aberdeen, Edinburgh and St. Andrews. The survey is based on information contained in official publications and it should be of use to those about to select a centre of engineering education and also to those called upon to assess the value of British engineering degrees or of those who hold them.

\section{Iron and Steel Institute: Co-operation with Local} Technical Societies

Arrangements have been made by the Council of the Iron and Steel Institute and the councils of various local technical societies for extending existing arrangements for co-operation between the Institute and such bodies. To this end, the Council of the Institute has agreed to extend the maximum age of associate membership from twenty-four years of age, as previously fixed, to thirty years of age in the case of associate members who are also members of local technical societies taking part in the scheme. It has also agreed to supply each year to the local societies, for presentation and discussion at local meetings, certain papers which have been presented at general meetings of the Iron and Steel Institute. One or two joint meetings each session between members of the local societies and members of the Iron and Steel Institute resident in the particular district will be arranged. It is hoped by these means usefully to extend the existing co-operation between the Institute and local technical societies, and particularly to encourage the study of problems connected with the manufacture and metallurgy of iron and steel, especially among the younger members of those societies. The secretary of the Iron and Steel Institute, 28 Victoria Street, London, S.W.1, will supply further information on request.

\section{Picture Telegraphy}

МетноDs of transmitting pictures by telegraphy have been known for the last ten years. In a suitably constructed photoelectric cell, the electric current through it can be made proportional to the light falling on it. If a picture in the form of a film negative be moved between a constant source of light and a cell in such a way that the light beam passes successively, line after line, through each minute area of the picture, the current transmitted will vary in intensity. The receiver is complicated, but the amount of light from a local source varies with the current received and falls on a photographic film which moves in step with the original film. A photoelectric cell can only distinguish light from darkness. Unlike the eye, it cannot distinguish form and colour. Photographs can be transmitted in this way by both wired and radio telegraphy. A recent remarkable achievement was the photograph of the Duke of Gloucester sent from Australia by the Marconi facsimile system of radio picture telegraphy. A still greater achievement was the transmission of the pictures on ten feet of cinematograph film showing the arrival of Scott and Campbell Black at Melbourne. An example of a news picture sent by the ordinary telegraph services between London and various Continental towns was the funeral of King Alexander at Belgrade. For ordinary commercial purposes, we think that picture telegraphy might be more widely used with advantage. Possibly the facilities it gives have not been sufficiently advertised. 